\title{
E-LEARNING IMPLEMENTATION IN ISLAMIC EDUCATION INNOVATION
}

\author{
A. Nurul Hidayat \\ Universitas Tadulako Palu, \\ Jl. Soekarno Hatta KM.9, Kota Palu, Sulawesi Tengah \\ Email: andinurulhidayat@yahoo.co.id
}

\begin{abstract}
Rapid development of information technology has influenced various aspects of life including Islamic education, This requires Islamic education institutions to be able to anticipate the developments by practicing learners need-based learning programs. One way to respond to information technology development is through implementation of elearning in Islamic education context. Electronic Learning is a new way in teaching and learning process through the uses electronic media such as internet-based learning material. It is expected e-learning system will be used more effective along with the development of technology and learning methods. The development of the E-learning system is also expected not only take into account the financial and profitability issues, but also learners psychological issues. This reaquires education institutions to accommodate the different individual personalities and learning strategies.
\end{abstract}

Abstrak. Perkembangan teknologi dan informasi yang cepat telah mempengaruhi dalam berbagai aspek kehidupan termasuk dalam bidang pendidikan Islam, Oleh karena itu, lembaga pendidikan Islam harus mampu mengantisipasi perkembangan tersebut dengan terus menerus mengupayakan suatu program yang sesuai dengan kebutuhan peserta didik. Maka dalam penerapan perlu melakukan inovasi pendidikan, salah satu inovasi pendidikan Islam dengan menerapkan e-learning, Elektronic Learning, merupakan cara baru dalam proses belajar mengajar yang menggunakan media elektronik khususnya internet sebagai sistem pembelajarannya. Harapan atas sistem E-learning di masa mendatang adalah penggunaan E-learning menjadi semakin efektif seiring dengan semakin berkembangnya teknologi dan metode pembelajaran yang digunakan. Pengembangan sistem E- 
learning juga diharapkan tidak hanya memperhitungkan masalah finansial dan profitabilitas, tetapi juga memperhatikan sisi psikologis peserta didik dan mampu mengakomodasi berbagai kepribadian dan cara belajar masing-masing peserta didik.

Key Words: Implementation, E-Learning, Islamic Education Innovation.

DOI: http://dx.doi.org/10.24239/jsi.v14i1.460.17-36

\section{Introduction}

The advancement of science and technology has resulted in changes in many aspects of social and moral order which was strongly upheld. Currently, the moral and social values tend to be ignored in which learners are required only to catch up in the field of science and technology if they want to stay updated ${ }^{1}$.

Science and technology also affects globalization. Globalization has created an increasingly open and interdependent world between nations and nations. All countries are not only open to each other, but also interdependent with each other. Due to mutual interdependence and openness, all countries are increasingly open to the effects of globalization. ${ }^{2}$ Globalization is an unstoppable effects and high volume of information penetrate each country everyday. The information not only affects knowledge but also affect the values of Islamic education. This includes changing in lifestyle habits such as dress patterns, food consumption, and recreational activities. Values become more uniform especially among young people in which affect their social, economic and religious aspects. Sometimes religious values are abandoned because the values are considered ancient and left behind. Meanwhile those who follow the cuurent trend are considered advanced and modern. In fact, they are unware of deterorioting the religious and moral values.

${ }^{1}$ Anshor, Transformasi Pendidikan Islam, First Edition (Jakarta: Gaung Persada Press, 2010). 12.

${ }^{2}$ Sudarwan Danim, Media Komunikasi Pendidikan: Pelayanan Profesional Pembelajaran dan Mutu Hasil Belajar, Second Edition (Jakarta: Bumi Aksara, 2015). 14. 
Globalization also demands readiness in the global life race. The competition requires Indonesia generation to prepare themselves in all aspects, such as intelligence, tenacity, toughness, innovation and so forth. The readiness is important to maintain competitiveness in global competition, and it is necessary to make a significant effort to save young generation as the successor to the struggle and the country's development. ${ }^{3}$

One way to counter the influence of globalization is through improving education system, especially Islamic education. The success and the failure of education system is determined determined by the state education system ${ }^{4}$. The existence of Islamic education is expected to improve learners personality. ${ }^{5}$ Islamic education aims to form the human values perfection which leads to the God worshipness and achieving happiness in the world and the hereafter. Islamic education is also expected to establish self-awareness of learners as a servant of God as well as its function as a khalifah on earth. ${ }^{6}$

To achieve the purpose of Islamic Education, it is necessary to use an effective learning strategy, determine teaching steps clearly, media, material, and methodology used in the teaching and learning activities.?

Media is the most important elements to support the success of the learning process. Ahmad Hidayat argues that the use of media in teaching and learning process can generate new desires, interests, motivation and stimulate learning activities as

\footnotetext{
${ }^{3}$ Yusufhadi Miarso, Menyemai Benih Teknologi Pendidikan, First Edition (Jakarta: Kencana, 2014). 11.

${ }^{4}$ Bambang Warsita, Teknologi Pembelajaran: Landasan dan Aplikasinya, Second Edition (Bandung: Alfabeta, 2008). 23.

${ }^{5}$ Ibid. 12.

${ }^{6} \mathrm{Ibid}$.

${ }^{7}$ Empy Effendi, E-Learning Konsep dan Aplikasinya (Yogyakarta: Kencana, 2011). 33.
} 
well as enhance leaners' psychological state. ${ }^{8}$ The use of media at the learning orientation stage will also greatly improve effectiveness in delivery learning contents. Other than generating motivation and interests of learners, media can also improve understanding, present data with interesting and reliable strategy, facilitate interpretation of data, and condense information.

The development of science and technology has a positive impact on Islamic education. Various types of learning media have emerged such as digital like textbooks and modules. Then, other types of media have also created such as tape recorders, television, movies, and others. Currently, those media have been used rampantly in particular for computer-based learning media and internet-based learning such as e-learning. E-learning is usually used in schools to complement face-to-face learning in the classroom.

Through e-learning, students can download learning materials anytime and anywhere. The students can also accomplish the task given by the teachers online and completing online examination. For Islamic lesson teachers, e-learning is also very useful in the delivery learning materials. For example, elearning can support the evaluation teaching because e-learning system can automatically correct the test results. Therefore, the author will focus the topic of this paper on "Implementation of ELearning in Islamic Education Innovation".

The tendency to develop e-learning as an alternative to learning in various Islamic educational institutions and training is increasing in line with developments in the field of communication and information technology. Infrastructure in the field of telecommunications that support the implementation of e-learning is no longer just a monopoly of big cities, but gradually

${ }^{8}$ Ahmad Hidayat, E-Learning Dalam Pembelajaran PAI (Yogyakarta: Andi Offset, 2002). 90. 
began to be enjoyed by those residing in small cities at the district level. As teh result, people at district are already able to use the internet facilities.

One of the challenges in Islamic education development in Indonesia is how to provide an educational system that can accommodate the size of learners and able to accelerate Islamic education with good quality. This is important for establishing a strong and intelligent Muslim society. One solution is to practice self-learning or distance learning through the use of technology such as E-learning. This paper provides an overview of educational methods regarding the use of technology teaching and learning process as well as it impact to the future development of Islamic education.

\section{Definition and E-Learning Characteristics}

Many experts outline the definition of e-learning from different points of view. Some common definitions on e-learning are outlined as follows:

- E-learning is a teaching and learning process that allows the delivery of teaching materials to learners using the internet platform or other computer network tools.

- E-learning is an educational system that uses electronic applications to support teaching and learning through internet, computer networks, and standalone computers.

- E-learning is all learning and teaching process which includes the use of computers to support of improving the quality of learning, including the use of mobile technologies such as PDAs and MP3 players. E-learning also use of web based teaching materials, hypermedia, multimedia CD-ROM or web sites, online discussion forums, collaborative software, e-mail, blogs, wikis, computer aided assessment, educational animation, simulations, games, learning management software, electronic voting systems, and 
others. It can also be a combination of different media usage. ${ }^{9}$

From the definitionm it can be concluded that the system or the concept of education that utilizes information technology in the process of teaching and learning can be referred to Elearning.

The characteristics of E-learning are included :

- Utilizing the services of electronic technology; Where teachers and learners, learners and fellow learners or teachers and fellow teachers can communicate easily.

- Utilizing the benefits of computers such as digital media and computer networks.

- Using self-learning materials stored on the computer which the material can be accessed by teachers and learners anytime and anywhere.

- Utilize computer technology to manage schedule, curriculum, learning progressm and materials relating to the administration of education any time. ${ }^{10}$

E-learning is understood as learning process carried out using electronic media both formal and informal context. In formal contect, e-learning is the use of electronic means in the curriculum, syllabus, subjects and tests which have been arranged based on the schedule agreed by the relevant parties (managers e-learning and learners themselves). Such e-learning usually involves high level of interaction and it is mandated by a company on its employees. The e-learning may also be a distance learning program which is managed by universities or companies which their business is to provide e-learning services to the public.

'Soekartawi, “E-Learning: Konsep Dan Aplikasinya," in Paper Presented in Balitbang Depdiknas Seminar ,18 Februari 2017(Jakarta, 2017). 12.

${ }^{10}$ Ibid. 6 
E-learning can also be done informally with simpler interactions. For example, e-learning use mailing lists, e-news letters or personal websites, organizations and companies to promote certain services, programs, knowledge or skills to wider community. E-learning is always identified with internet usage in learning and teaching process. Tools to delivery e-lerining is very diverse which include internet, intranet, CD, DVD, mp3, PDA, and others. The use of internet in e-learning generally base on consideration that the internet support wide range of access. Some educational institutions and companies also use an intranet network as an e-learning medium to reduce cost.

There are some understanding related to e-learning as follows: ${ }^{11}$

\section{Distance Learning}

E-learning is a distance learning that utilizes computer technology, computer network or Internet. E-learning allows learners to study education material through online computers networl in their own places without attending classroom. Elearning is also understood as a form of web-based learning that can be accessed from a local intranet or the internet. E-learning material does not have to be distributed on-line either through local network or internet, but it can be distributed off-line using CD / DVD. In this case, teachers may develop an application and learning materials as required by students and then the application and material are distributed through CD or DVD. The learners use the CD/DVD at their own places.

In response to Decree of Minister of National Education No.107/U/2001 concerning the Implementation of Higher Education Program, some universities have developed their

\footnotetext{
${ }^{11}$ Antonius Aditya Hartanto and Onno W. Purbo, E-Learning Berbasis PHP dan MySQL (Jakarta: Elex Media Komputindo, 2012). 34.
} 
capacity to conduct open and distance education using elearning. ${ }^{12}$

\section{Teaching with Computers}

E-learning is delivered by using computer devices. Most of the devices are equipped with multimedia devices such as a CD drive, internet connection, and local intranet. With a computer is connected to an intranet or the internet, learners can participate in e-learning programs. The number of learners who can participate is not limited by class capacity. The subject matter can also be presented with a higher standard quality compared to conventional class which depends on the condition of a teacher.

\section{Teaching is supported by Specific Experts.}

Although e-learning seems to be provided solely through a computer device, e-learning can be prepared, supported, and managed by a team of experts in their own fields which include:

- Subject Matter Expert (SME) or a trained resource person;

- Instructional Designer (ID), a person who systematically design material from SME become e-learning materials by incorporating elements of teaching methods to make the material more interactive, easier and more interesting to learn.

- Graphic Designer (GD), a person who transforms text material into graphic form with interesting images, colors, and layouts for effective and interesting learning and teaching.

- Expert in the field of Learning Management System (LMS); a person who manages systems on websites to manage traffic interaction between instructors and learners, and between learners with other learners.

${ }^{12}$ Made Wena, Strategi Pembelajaran Inovatif Kontemporer: Suatu Tinjauan Konseptual Operasional (Jakarta: Bumi Aksara, 2009). 212-213. 
Learners can access modules, accomplish tasks, do tests, access timetable of discussion with virtual instructors, other resource, and other learners. Through this LMS, learners can also accomplish the given tasks, do tests, see the score and rank based on the score obtained. E-learning is not solely given by machines, but it is also accompanied by experts in their own fields.

\section{Advantages and Disadvantages of E-Learning}

There are several advantages or disadvantages of using the internet Islamic education system which includes: ${ }^{13}$

- Availability of e-moderating facilities, where teachers and learners can communicate easily. They can communicate easily without being limited by distance, place and time.

- Educators and learners can use instructional materials or structured and scheduled learning instructions through the internet. This can be assessed from every region without limited by geaographic area.

- Learners can learn teaching materials any time and anywhere if needed because the teaching materials are stored in online computer systems.

- If the learner requires additional information relating to the material, he / she can access the internet easily.

- Both educators and learners can conduct online discussions which involve a large number of participants, thus adding knowledge and wider insight.

- When learning is practiced online, the learners may become more active.

- E-learning is more efficient. For example for those who stay away from school.

\footnotetext{
${ }^{13}$ Suteja, Memasuki Dunia E-Learning (Bandung: Informatika, 2016). 24.
} 
The use of Internet e-learning learning also has some disadventages which includes: ${ }^{14}$

- Lack of interaction between teachers and learners or even among learners themselves. This lack of interaction can slow the formation of values in the learning and teaching process.

- The tendency to ignore the academic aspects or social aspects and vice versa may encourage the growth of business / commercial aspects in education system.

- The learning and teaching process tends to resemble training programs rather than educational process.

- Teachers are required not only to poses conventional teaching techniques (face-to-face), but they are also required to know learning techniques using information and communication technology (ICT).

- Learners who do not have high learning motivation tend to fail.

- Not all areas provide Internet facility.

- Lack of staff with good Internet skill.

- Lack of mastery of computer language.

\section{The Use of e-Learning in Islamic Education}

The term e-learning consists of the letter " $e$ " which stands for "electronic" and "learning" which means "to learn". Thus elearning can be interpreted as learning by using electronic devices, especially computer devices. The term e-learning can also be defined as a form of information technology applied in the field of education in cyberspace context. However, the term elearning is more appropriately defined as making a transformation of the existing learning process in school/

\section{${ }^{14}$ Ibid. 25.}


madrasah, or college into a digital form which facilitated by internet technology. ${ }^{15}$

Studies conducted by Hamzah B. Uno strongly support the development of e-learning, who states that computer-based learning is very effective, allowing 30\% better education, $40 \%$ less time, and 30\% cheaper cost. The World Bank in 1997 has announced the Global Distance Learning Network (GDLN) program which has partners in 80 countries around the world. Through the GDLN, the World Bank provides 5 times more elearning to the students (from 30 to 150 students) at a cost of $31 \%$ cheaper. ${ }^{16}$

The use of e-learning in the learning process is rampant, because the e-learning system has advantages such as: improving the interaction of learning (enhance interactivity), facilitate the interaction from anywhere and at anytime (time and place flexibility), wider area (potential to reach a global audience), and facilitate the improvement and storage of learning materials (easy updating of content as well as it has archivable capabilities). ${ }^{17}$

E-learning system provide benefits for both teachers and learners. The principle of e-learning includes: first, e-learning as a tool of learning process to solve problems, generate creativity, make learning process easier, directed and meaningful; Secondly, e-learning as an alternative in educational system has high-techhigh-touch principle which the process is more dependent on advanced technology and more importantly the high touch aspect benefits teachers or learners; Third, adjust e-learning with the

\footnotetext{
${ }^{15}$ Munir, Pembelajaran Jarak Jauh Berbasis Teknologi Informasi dan Komunikasi (Bandung: Alfabeta, 2009). 147.

${ }^{16}$ Hamzah B. Uno, Model Pembelajaran: Menciptakan Proses Belajar Mengajar Yang Kreatif Dan Efektif (Jakarta: Bumi Aksara, 2007). 40.

${ }^{17}$ Munir, Pembelajaran Jarak Jauh Berbasis Teknologi Informasi dan Komunikasi. 174-176.
} 
readiness of teachers, learners, facilities and culture learning system. $^{18}$

Internet and e-lerning applications are now widely used in the learning process. This becomes more complicated when it is applied to Islamic education process because Islamic teachers and Islamic education methods require face-to-face interaction because the learning content is dogmatic. In addition, online content is often considered as doubtful by Islamic teacher. This shows lack of trust from Islamin teachers towards online contents.

According to Bambang Warsita there are two approaches that can be used by teachers in using or implementing elearning: ${ }^{19}$

- Theme-Centered Approach. This approach is practiced with the following steps: Define the topic. Determine the learning objectives. Determine the learning activities by utilizing relevant information technology to achieve the learning objectives.

- Software-Centered Approach. This approach is begun with identifying information technology. Then the teachers plan a relevant learning strategy for a particular learning topic.

\section{Teaching Model With E-learning Technology and Its Impact on Islamic Education}

The need for e-learning is increasing from year to year because e-learning serve as better alternative media in implementing Islamic education. It is also a tool to achieve a competent in the world of education. The emergence of elearning has a major impact on the world of Islamic education. Isalmic education stakeholders and users have to respond to the emergence of e-learning. The learners enjoy new learning

${ }^{18}$ Ibid. 201.

${ }^{19}$ Warsita, Teknologi Pembelajaran: Landasan Dan Aplikasinya. 151-152. 
experience and better interaction than the conventional class. Access to information also increased dramatically. In addition, students can also choose their own way of study that best suited to their personality when attending e-learning classes.

E-Learning as a new discourse is considered more appropriate for learners with limited time, learning places, geographical distance, spacing, and the need to learn in their own place. This can be fulfilled when e-Learning is implemented. Thus, e-Learning has increased the opportunity for individuals to get their prefered education as well as accelerate the creation of a knowledge society. ${ }^{20}$

Educators experience the impact of using e-learning on their teaching methods. They need to adapt in the way of teaching in delivering teaching materials which is different from the conventional method. E-learning system also requires expertise in providing interesting learning materials efficiently.

Islamic educational institutions also experience better impact from the use of e-learning, especially relating to education cost reduction. The institutions are also responsible for conducting training to their teaching staff and providing technology to support e-learning practice. Education institutions discusssed above are not only academic education institutions but also, but also includes education in business environments. For example, trainings held by a company for employees. Learning with e-Learning has many advantages, as follows:

- Providing an interesting and meaningful experience for learners because the ability to interact directly. Learning materials are understood in more meaningful, easy to understand, easy to remember and easy recall.

- E-learning improves the students' level of understanding and memory (high retention of information) due to varied

${ }^{20}$ Eti Rochaety, et. al., System Informasi Manajemen Pendidikan (Jakarta: Bumi Aksara, 2006)., 78. 
content, interesting interaction, and better interaction with other e-learner and instructors.

- The ability to cooperate in online community enhance the process of information transfer and communication. Each actor will not miss interaction with learning sources or learning materials.

- Centralized administration and management, making elearning easier to operate and implement.

- Save or reduce the cost of education, such as reduced fees for paying teachers, accommodation fees and students transportation fees because they do need to attend clasroom.

- Learning through Internet increase students attention in learning process. This means learner does not depend entirely on the teacher. ${ }^{21}$

E-learning practices must be supported by internet services. Internet provides complete learning sources which teachers accomplish their teaching tasks. In the past, the teaching-learning process was dominated by the teacher's role called "the era of teacher", in which the learners only listen to the teachers' instruction. Later, the learning and teaching process was dominated by the teacher and books. Currently, learning and teaching process is dominated by the teacher, bookn and technology (the era of teachers, books and technology). Other positive effects of using e-learning in education are as follows:

- E-learning is flexible because learners can learn anytime, anywhere, and with different types of learning.

- E-learning saves teaching time and learning process.

- Reduce travel costs.

${ }^{21}$ Warsita, Teknologi Pembelajaran: Landasan dan Aplikasinya. 20 
- Save overall education costs (infrastructure, equipment, books).

- Re-learning reach a wider geographic area and train students to study independently ${ }^{22}$.

However, e-Lerning also has several weaknesses include the following:

- E-learning involves the use information technology in teaching, some teachers or students are information technology illaterate. This may constraine them to access elearning.

- Creating interactive e-learning requires programming skill and it takes a long time built an application.

- E-learning requires a good and high cost technological infrastructure.

- Not everyone wants to use E-learning as a medium of learning.

- Human resources are limited and not everyone can use them. ${ }^{23}$

Education is a transformation process with specific purposes. Education consist of elements such as: Islamic material, lecturers are educators, educational objects means people who learn, methods, and instruments of education.

\section{E-learning Method Development in Islamic Education}

E-learning development should be designed carefully based on teaching objectives. If e-learning is designed to include Internet-based learning, it should consider carreful development.

\footnotetext{
${ }^{22}$ Deni Darmawan, Dasar Teknologi Informasi Dan Komunikasi (Bandung: UPI PRESS, 2006). 56

${ }^{23}$ Hanny Kamarga, Belajar Sejarah Melalui E-Learning; Alternatif Mengakses Sumber Informasi Kesejarahan (Jakarta: Inti Media, 2014). 12.
} 
According to Bambang, there are three possibilities in the development of Internet-based learning system, namely web course, web centric course, and web enhanced course. ${ }^{24}$

Web course is the use of the Internet for educational purposes, in which learners and teachers are completely separate and not required face-to-face. All teaching materials, discussions, consultations, assignments, exercises, exams, and other learning activities are fully submitted via the internet. In other words this model uses a remote system.

Web centric course is the use of the Internet that combines distance learning and face to face (conventional) mode. Some of the material is delivered over the internet, and partly through face-to-face interaction. In this model, teachers can give instructions to learners to study the subject matter through the web that has been designed. Learners are also given directions to find other sources from relevant sites. In the face to face interaction, learners and teachers focus to discuss the findings of materials that have been learned from the internet. The web enhanced course model is the use of the internet to support the improvement the quality of learning conducted in the classroom.

Another internet function is to provide enrichment and communication between learners and teachers, fellow learners, group members, or learners with other resource persons. Therefore, the role of teachers in this case is required to master the technique of finding information on the internet, guiding the learners to find relevant sites, presenting material through the web, providing guidance and communication via the internet, and other skills. E-learning development does not merely present teaching material via on-line, but the material must be communicative and interesting.

${ }^{24}$ Warsita, Teknologi Pembelajaran: Landasan dan Aplikasinya. 112. 
The learning matterial is designed as if learners learn directly from their teachers through the computer screen connected through the internet network. To be able to produce interesting and desirable e-learning material, it requires three things; "simple, personal, and fast". A simple system will make it easier for learners to take advantage of existing technologies. Students can also get benefits from the provided computer panel which may reduce time to introduce the e-learning system. As teh result, participants' learning time can be reduced and it can be used for the learning process rather than to learn how to use elearningnya. ${ }^{25}$

Teacher skills requirement include the teachera are able to interact and communicates effectively with their students in classroom. With a more personal approach and interaction, learners progress can monitored and assist them when they have learning problems. This will make the learners feel comfortable when using e-learning. E-learning should also be supported by the speed and quick response to complaints and the needs of learners. Thus, improvement of learning can be carried out by the teachers or managers. Onno W. Purbo suggests to use game theory to improve attractive of learning. This theory was emerged after an observation of the behavior of computer game fans. Playing computer games is very exciting. The players will be made to drift with the characters it plays through the computer.

Learners sit for hours and play the game with pleasure. This phenomenon is very interesting to be ralated with e-learning design. Teachers should create an e-learning system that is able to attract the learners to follow every step of learning as they did when playing a game. Application of games theory in designing elearning material needs to be considered because basically every human like games.

\footnotetext{
${ }^{25}$ Suteja, Memasuki Dunia E-Learning. 98.
} 
In summary, e-learning needs to be created as if the learners are learning in conventional mode. The different is that the material is transferred into the digital system via the internet. Therefore, e-learning needs to adapt the common elements used in conventional learning systems. For example, the learning starts from the formulation of operational and measurable objectives, and then there are apperception or pre test, motivation, communicative language, clear material description, concrete examples, problem solving, question and answer, discussion, post test, assignments and follow-up activities. Therefore designing elaarning needs to involve relevant parties, such as teachers, material experts, communication experts, programmers, artists, etc.

\section{Conclusion}

On type of education which may be available in the 21st century is E-Learning. It is learning through the use of computer technology. The Internet e-learning is a learning approach through computer devices connected to the internet, where learners seek to obtain learning materials to suit their needs .

The main function of the internet is the medium for communication and information exchange. E-mail allows us to send mail and other types of files to Internet users. The most popular internet facility is WWW (World Wide Web), which is a relatively new of the internet facilities and it functions to send and receive Electronic Mail.

There are number of challenges for policy makers and Elearning designers. Therefore I agree that in the conventional education system, e-learning function is to enrich the insight and understanding of learners, as well as the process of familiarity with internet technology. E-learning as an alternative method for Islamic education provides many benefits and advantages. However, e-learning also has some limitations that should be 
taken into account by any party wishing to participate in Elearning process.

Although E-learning was originally intended to substitute traditional learning methods, e-learning has not been able to replace the roles and advantages of conventional learning methods. This is because e-learning method is not able to match the superiority of conventional face-to-face interaction methods. As a result, e-learning with its various advantages is more suitable to serve as a complement to conventional learning methods in particular for Islamic education.

It is expected Islamic education will use e-learning system more effectively along with the development of technology and learning method. The development of e-learning system not only focus financial and profitability issues, but also on psychological issues to accommodate various personalities and learning strategies.

\section{References}

Anshor. Transformasi Pendidikan Islam. First Edition. Jakarta: Gaung Persada Press, 2010.

Danim, Sudarwan. Media Komunikasi Pendidikan: Pelayanan Profesional Pembelajaran dan Mutu Hasil Belajar. Second Edition. Jakarta: Bumi Aksara, 2015.

Darmawan, Deni. Dasar Teknologi Informasi dan Komunikasi. Bandung: UPI PRESS, 2006.

Effendi, Empy. E-Learning Konsep dan Aplikasinya. Yogyakarta: Kencana, 2011.

Hartanto, Antonius Aditya, and Onno W. Purbo. E-Learning Berbasis PHP dan MySQL. Jakarta: Elex Media Komputindo, 2012.

Hidayat, Ahmad. E-Learning dalam Pembelajaran PAI. Yogyakarta: Andi Offset, 2002.

Kamarga, Hanny. Belajar Sejarah Melalui E-Learning; Alternatif Mengakses Sumber Informasi Kesejarahan. Jakarta: Inti Media, 2014. 
Miarso, Yusufhadi. Menyemai Benih Teknologi Pendidikan. First Edition. Jakarta: Kencana, 2014.

Munir. Pembelajaran Jarak Jauh Berbasis Teknologi Informasi dan Komunikasi. Bandung: Alfabeta, 2009.

Rochaety, Eti, et. al. System Informasi Manajemen Pendidikan. Jakarta: Bumi Aksara, 2006.

Soekartawi. "E-Learning: Konsep dan Aplikasinya." In Paper Presented in Balitbang Depdiknas Seminar ,18 Februari 2017. Jakarta, 2017.

Suteja. Memasuki Dunia E-Learning. Bandung: Informatika, 2016.

Uno, Hamzah B. Model Pembelajaran: Menciptakan Proses Belajar Mengajar Yang Kreatif dan Efektif. Jakarta: Bumi Aksara, 2007.

Warsita, Bambang. Teknologi Pembelajaran: Landasan dan Aplikasinya. Second Edition. Bandung: Alfabeta, 2008.

Wena, Made. Strategi Pembelajaran Inovatif Kontemporer: Suatu Tinjauan Konseptual Operasional. Jakarta: Bumi Aksara, 2009. 